\title{
Die aard en aanbieding van die leksikografiese definisie*
}

\section{F.J. Lombard, Buro van die Woordeboek van die Afrikaanse Taal}

\begin{abstract}
The Nature and Presentation of the Lexicographical Definition. The lexicographical definition is still the most important entry in a dictionary article. It is important that this significant entry, like other dictionary entries, should rely on the dynamics of real language. To achieve this, it is necessary that the lexicographer must base his definitions on citations from the spoken and written language. This important aspect of lexicography is touched on. I also take a look at different ways that the lexicographer can use to compile definitions. The best known methods probably are genus and differentiae definitions, synonym definitions, circle definitions and descriptive definitions. Various criteria can be applied to test the lexicographical definition. I limit myself to comprehensiveness, clarity, accuracy, consistency, autonomy, objectivity and neutrality, which I believe to be the most important criteria.
\end{abstract}

Keywords: LEXICOGRAPHICAL DEFINITION, REAL LANGUAGE, GENUS AND DIFFERENTIAE DEFINITIONS, SYNONYM DEFINITIONS, CIRCLE DEFINITIONS, DESCRIPTIVE DEFINITIONS, COMPREHENSIVENESS, CLARITY, ACCURACY, CONSISTENCY, AUTONO MY, OBJECTIVITY, NEUTRALITY, COMPONENTLAL ANALYSIS, USER-FRIENDLINESS, POLYSEMY

Opsomming: Die leksikografiese definisie word steeds beskou as die belangrikste inskrywing in ' $n$ woordeboekartikel. Soos by ander woordeboekinskrywings, is dit belangrik dat hierdie sentrale inskrywing by die taalwerklikheid moet aansluit. Om dit te bereik, moet die leksikograaf sy definiense sover moon lik op voorbeeldmateriaal uit die geskrewe en gesproke taalgebruik baseer. Na hierdie onderliggende aspek van die leksikografiese definisie word daar gekyk. Daar word ook aandag gegee aan enkele maniere waarop die leksikografiese definisie aangebied kan word. Van hierdie maniere is die genus-differentiae-definisie, die sinoniemdefinisie, die sirkeldefinisie en die deskriptiewe definisie waarskynlik die bekendste. Na die verskeie kriteria wat toegepas kan word by die beoordeling van definiense word daar ook gekyk. Van hierdie kriteria word volledigheid, helderheid, akkuraatheid, konsekwentheid, selfstandigheid, objektiwiteit en neutraliteit aan bod gestel, aangesien hulle na my mening die betekenisvolste kriteria is.

Hierdie artikel is 'n verkorte en aangepaste hoofstuk uit 'n D.Litt.-verhandeling 'n Metaleksikografiese fundering oan Afrikaanse skoolwoordéboeke wat in Desember 1990 deur die Universiteit van Stellenbosch aanvaar is. 
Sleutelwoorde: LEKSIKOGRAFIESE DEFINISIE, TAALWERKLIKHEID, GENUS-DIFFERENTIAE-DEFINISIES, SINONIEMDEFINISIES, SIRKELDEFINISIES, DESKRIPTIEWE DEFINISIES, VOLLEDIGHEID, HELDERHEID, AKKURAATHEID, KONSEKWENTHEID, SELFSTANDIGHEID, OBJEKTIWITEIT, NEUTRALITEIT, KOMPONENSIËLE ANALISE, GEBRUIKERSVRIENDELIKHEID, POLISEMIE

\section{Inleidend}

Woordeboeke word die meeste vir betekenisverklaring gebruik. Omdat die leksikografiese definisie steeds as die sentrale inskrywing van 'n woordeboekartikel beskou word, is definiëring van lemmas een van die belangrikste take van die leksikograaf.

Die soort definisie wat in woordeboeke gebruik word, staan bekend as die leksikografiese definisie. Volgens Eksteen (1967: 12) berus dié definisie op sekere historiese feite. Robinson (1950: 45) sê in dié verband: "Lexical definition is a form of history. It refers to the real past. It tells what certain persons meant by a certain word at a certain less or more specified time and place. In a 'modern' dictionary the time meant is the most recent period down to the instant of writing and there is a strong expectation that the same persons will continue to use this word in the same way for a considerable time after the publication of the dictionary." Alhoewel die leksikografiese definisie nie sonder meer gelyk aan die leksikale definisie is nie, is hulle in die konteks hierbo dieselfde.

Robinson dui hierbo een van die belangrikste aspekte van die leksikografiese definisie aan. 'n Definiens word naamlik saamgestel nadat die betekenis van 'n leksikale item ontleed is. Die optrede van die leksikale item in die taalgebruik van sprekers en skrywers moet in ag geneem word by die betekenisontleding daarvan. Dit is die leksikograaf se plig om die definiens van 'n leksikale item uit die taalwerklikheid te "distilleer". Die skep van 'n leksikografiese definisie berus daarom nie op die vindingrykheid van die leksikograaf nie, maar op drie persone se betrokkenheid, naamlik die leksikograaf self, die gebruiker vir wie die betekenis gedefinieer word, en die gebruiker wat aan die woord sekere betekenisse heg (Eksteen 1967: 15). As daar nie voldoende aandag gegee word aan die derde persoon nie, sal 'n woordeboek ontspoor deurdat dit nie berus op objektiewe weergawe van die taalgebruik nie.

'n Definiens is dus uiteindelik niks anders as 'n beskrywing van wat gebruikers van 'n woord daarmee bedoel het nie. Die leksikograaf se formulering is ' $n$ verwoording van die abstraksie wat hy gemaak het uit die gemeenskaplike wete van taalgebruikers. Gove, aangehaal in Eksteen (1965: 85), laat hom soos volg hieroor uit: "... a definition, to be adequate, must be written only after analysis of usage". 


\section{Enkele maniere waarop gedefinieer kan word}

\subsection{Genus-differentiae-definisies}

'n Tradisionele en eenvoudige manier waarop gedefinieer kan word, kom van Aristoteles se analise dat die woord wat gëdefinieer moet word, beskryf kan word deur gebruik te maak van 'n genus en differentiae. Baie leksikograwe en leksikoloë glo dat dit die beste en eenvoudigste metode is wat gebruik kan word.

Gove $(1985: 58,59)$ wys daarop dat die woord wat gedefinieer of die voorwerp wat beskryf moet word, die beste binne die essensiële bewoording van die genus en differentiae van 'n analitiese definisie georiënteer kan word. By die genus-differentiae-metode word die woord eers in 'n oorkoepelende klas (die genus) geplaas en dan word dit deur unieke kenmerke (die differentiae) van alle ander dinge in daardie klas onderskei (Landau 1984: 120). Dié werkwyse is so eenvoudig dat dit die leksikograaf tot ' $n$ oorvereenvoudigde definiens kan verlei. Hierdie manier van definieer vereis daarom dat die leksikograaf sy genus en die daaropvolgende differentiae sorguuldig moet kies sodat sy gebruikers nie moeite het met die verstaan van enige aspek van die definiens nie. Die leksikograaf word by die gebruik van dié metode van definieer in sekere gevalle verplig om meer differentiae, wat neerkom op (noodsaaklike) saakbesonderhede, aan te bied.

Dié manier van definieer het daarom sy beperkinge. Dit kan byvoorbeeld nie geredelik op alle abstrakte begrippe toegepas word nie. Gove se stelling hierbo is dus 'n oorvereenvoudiging. Soms is die differentiae doodgewoon te skamel om onderskeidend genoeg te wees. ' $n$ Voorbeeld wat hier genoem kan word, is Nasionale Woordeboek (voortaan NW) se hantering van kwikstertjie: "voelt jie met ' $n$ wipperige stert". Die genus plaas dadelik diegene wat onbekend is met kwikstertjies in die prentjie, maar die differentiae is te skamel, want daar is ander voëls wat ook hulle sterte wip. As sodanig slaag die definiens net ten dele.

Die genusaanduiding moet volkome duidelik en verstaanbaar wees sodat dit die lemma reeds skerp afbaken en vir die gebruiker plaas (Gove 1985: 59). In die bogenoemde geval is die genus skerp afgebaken, maar die probleem lê in die differentiae wat nie onderskeidend genoeg is nie. Gove wys ook daarop dat die genuswoord deur modifiseerders bepaal of beperk moet word sonder dat die oriëntasie daarvan in die gedrang gebring word. By die definiëring van leeu of tier is die genuswoord byvoorbeeld roofdier, en 'n modifiseerder wat hier sal tuishoort, is groot omdat daar ander roofdiere is wat baie kleiner is as leeus en tiere, byvoorbeeld luiperds, jagluiperds, rooikatte, jaguars, bergleeus, ensovoorts. Die leksikograaf moet versigtig wees dat hy nie te moeilike modifiserende woorde gebruik in sy poging om die genuswoord akkuraat te plaas nie. 
In bogenoemde geval sal daar nog differentiae aangebied moet word omdat "groot roofdier" nie 'n adekwate definiens van tier of leeu is nie.

Dié genus-differentiae-metode van definieer is kontrasterend van aard. Deur gebruik te maak van 'n genus word soortgelyke sake in 'n kategorie geplaas en daardeur word die verskille, soos aangedui deur die differentiae, skerp in kontras gestel. Volgens Ayto (1983: 90) moet die genus, om maksimale definiërende krag te hê, nie te algemeen en nie te spesifiek wees nie. Die wins van dié soort definiens is die eenvoud daarvan en die plasing van die lemma in 'n breë semantiese kategorie wat meebring dat die gebruiker onmiddellik georiënteer word (deur die genus). Dit is dus 'n gebruikersvriendelike definiens.

Louw (1985: 60) stel ook 'n tipe analitiese definisie voor waarin hy drie betekeniskomponente onderskei waarvan veral die eerste twee vir die leksikograaf deurslaggewend kan wees by die maak van 'n definiens. Die drie komponente wat Louw onderskei, is 'n gemeenskaplike, 'n diagnostiese en 'n supplementêre komponent. Die gemeenskaplike komponent word verteenwoordig deur ' $n$ baie algemene betekeniswaarde, met ander woorde iets wat die lemma wat gedefinieer word, gemeenskaplik met ander leksikale items kan hê. As sodanig verteenwoordig die gemeenskaplike komponent 'n soort genus. Die diagnostiese komponent vernou die betekenisbeskrywing aansienlik, en as dit nodig sou wees om die lemma nog akkurater te plaas, dan kan die supplementêre komponent, wat meer detail gee, aangewend word. Die twee komponente kom dan rofweg met differentiae ooreen. Volgens Gouws (1985: 36) kan die gebruik van dié betekeniskomponente die leksikograaf in staat stel om sy betekenisverklaring te verbeter.

As voorbeeld sou die lemma motorfiets kon dien. 'n Kort definiens daarvan sou die volgende kon wees: "Tweewielige kragaangedrewe voertuig, gewoonlik groter en kragtiger as 'n bromponie". Voertuig is hier 'n gemeenskaplike betekeniskomponent met byvoorbeeld fiets, bromponie, skip, trein, vliegtuig, motor, ensovoorts. Tweewielig is 'n diagnostiese komponent wat motorfiets, bromponie en fiets onderskei van die ander vervoermiddels. Om motorfiets van fiets en bromponie te onderskei, is daar verdere diagnostiese komponente nodig. Kragaangedrewe onderskei bromponie en motorfiets van fiets, en groter en kragtiger onderskei motorfiets van bromponie.

'n Definiens van jagluiperd sou as verdere voorbeeld kon dien: "baie vinnige, gespikkelde roofdier, kleiner as 'n luiperd". Roofdier is 'n gemeenskaplike betekeniskomponent. Die deel van die definiens, gespikkeld, baie vinnig, tree as diagnostiese komponent op en onderskei 'n jagluiperd van 'n leeu, tier, rooikat, ens., maar gespikkeld en baie vinnig beskryf 'n jagluiperd waarskynlik nog nie genoegsaam nie. Vir die gebruikers wat nou al kon uitmaak dat die definiens. afstuur op óf 'n luiperd (wat volgens die oordeel van baie mense ook heel vinnig is), óf 'n jagluiperd, moet nog inligting gegee word en die frase, kleiner as ' $n$ luiperd, tree hier diagnosties op en plaas die dier akkuraat vir die gebruiker. 
Een komponent kan in bepaalde gevalle sowel gemeenskaplik as diagnosties wees. Die komponent dier kan byvoorbeeld van toepassing wees op ' $n$ leeu, 'n koedoe, 'n muis, 'n olifant, 'n skaap, 'n hond, 'n koei, ensovoorts (gemeenskaplik), en die komponent onderskei ook enigeen van bogenoemde van byvoorbeeld plante of mense (diagnosties).

\subsection{Sinoniemdefinisies}

\subsubsection{Inleidend}

Een van die bondigste maniere waarop lemmas in woordeboeke gedefinieer word, is deur middel van sinonieme. In so 'n geval is die definiens ' $n$ sinoniem van die definiendum.

Dit gebeur dikwels dat woordeboeke van sinoniemdefiniense gebruik maak ter wille van bondigheid. Hoe kleiner die woordeboek dan ook is, hoe meer is dit die geval (Zgusta, 1971: 261). Die betekenis van die definiendum word in die geval van sinoniemdefiniense nie verklaar nie, maar deurdat daar 'n sinoniem van die definiendum aangebied word, word die gebruiker verwys na ' $n$ ander lemma wat as betekenisverklaring van die definiendum kan dien. By die verwysde lemma word die sinoniem (vanwaar verwys is) ná die definiens aangebied. Tussen die twee optredes bestaan daar ' $n$ aantoonbare wisselwerking wat deur die toepassing van kruisverwysing ekplisiet gemaak word.

Volgens Geeraerts en Janssens (1982: 20) is die eenvoudigste soort definiens wat in die leksikografie gebruik kan word, juis die sinoniemdefinisie. Hulle verkies die analitiese definisie bo die sinoniemdefinisie omdat die analitiese definisie volgens hulle baie meer genuanseer is as die sinoniemdefinisie. Volgens hulle word 'n woord se gebruiksmoontlikhede beter teenoor mekaar afgebaken deur die analitiese definisie as deur ' $n$ sinoniemdefinisie. Hierdie siening is nie noodwendig juis nie. 'n Sinoniemdefinisie waarvan die kruisverwysing korrek is, is ' $n$ bondige en ondubbelsinnige wyse van definiëring met ' $n$ kruisverwysende waarde na 'n omvattender artikel waarin gebruiksmoontlikhede ook teenoor mekaar afgebaken word.

\subsubsection{Probleme rondom sinoniemdefinisies}

Daar kan probleme rondom die aanwending van sinoniemdefinisies voorkom, onder andere probleme vir die gebruiker, en opstellers van woordeboeke sal deeglik moet besin of hulle die gebruiker werklik tegemoet kom as hulle sinoniemdefiniense aanbied wat weliswaar kort is, maar wat soms 'n vlag is wat nie altyd die lading dek nie. Bondigheid behoort as beginsel nie voorkeur bo helderheid en akkuraatheid te kry nie, maar ongelukkig gebeur dit soms met die aanbied van sinoniemdefiniense. Korrekte sinoniemdefinisies waarby 
sirkeldefiniëring deur 'n onbesproke kruisverwysingsisteem vermy word, is egter 'n ekonomiese en sinvolle wyse van definiëring.

Zgusta (1971: 90) noem drie aspekte van leksikale betekenis: die denotasie wat verwys na die aanwysbare eienskappe van die ding of konsep wat gedefinieer word, die konnotasie wat verwys na geassosieerde eienskappe, en die omvang van toepassing wat verwys na die konteks(te) waarin 'n woord gebruik kan word. Hy voer aan dat woorde slegs sinoniem is as die woorde ten opsigte van al drie hierdie aspekte ooreenstem.

BäckJund (1985: 65) sluit by Zgusta aan as hy daarop wys dat baie sprekers verkeerdelik glo dat sinonieme min of meer uitruilbaar is terwyl hulle in werklikheid duidelik van mekaar onderskei kan word deurdat sekere kontekste net die aanwending van een sinoniem kan toelaat terwyl 'n ander sinoniem in die konteks geblokkeer word. Ook Gouws (1985: 41) en Kipfer (1984: 67) noem dat daar besware teen die sinoniemmetode kan wees omdat daar dikwels klein verskille is tussen woorde wat as sinonieme beskou word. Die leksikograaf moet tussen sinonieme wat gedeeltelik ooreenkom en sinonieme wat absoluut ooreenkom, onderskei. Absolute sinonieme kan mekaar volgens Gouws in alle kontekste vervang terwyl dit nie die geval met gedeeltelike sinonieme is nie.

Baie woordeboeke bied woorde as absolute sinonieme aan terwyl hulle net gedeeltelik sinoniem met mekaar is. Twyfelagtige sinoniemparadigmas word ook na die definiens aangebied. Aangesien daar min woorde is wat werklik volledig sinoniem met mekaar is, moet die leksikograaf baie omsigtig te werk gaan wanneer hy van sinoniemdefiniëring gebruik maak. Die feit dat sommige "sinonieme" minder sinoniem is as wat die leksikograaf vermoed, is nie al problematiek ten opsigte van sinoniemaanbieding nie. Dit gebeur dikwels dat ' $n$ leksikograaf een definiendum in terme van ' $n$ ander verklaar en dat die definiens van die laaste definiendum weer na die eerste verwys word. In so 'n geval het 'n mens met 'n sirkulêre betekenisaanbieding te make. So 'n werkwyse help die gebruiker natuurlik niks, want die definiendums word nie vir hom verklaar nie. Al wat hy te wete kom, is dat twee definiendums deur die opsteller as sinonieme beskou word.

In handwoordeboeke soos Handwoordeboek van die Afrikaanse Taal (voortaan HAT) en die NW kom daar baie sirkulêre sinoniemdefiniense voor en dit gebeur ook soms dat 'n woord waarna as sinoniemdefiniens verwys is, nie as verklaarde lemma opgeneem word nie. Sinonieme of byna-sinonieme is ook dikwels polisemies van aard en hulle behoort eers ondubbelsinnig gemaak te word voordat hulle gebruik kan word. Vergelyk die voorbeeld van mobiel wat hieronder gebruik word. Normaalweg kan sinonieme ondubbelsinnig gemaak word deur goeie kruisverwysing waarin die nommer van die betekenisonderskeiding wat gebruik word, vir die gebruikers aangedui word.

Sirkulariteit is 'n wesenlike gevaar by die maak van definiense. Die NW bied die volgende by meubel aan: "stuk huisraad bv. ' $n$ tafel, stoel, kas, bed; meubelstuk". By huisraad word die volgende aangebied: "meubels en ander toerusting 
waarmee ' $n$ woonhuis ingerig word". By meubel word daar dus verwys na huisraad en by laasgenoemde word daar na meubel verwys. Omdat hierdie definiense nie volledig sirkulêr is nie, sal die gebruiker waarskynlik nie probleme ervaar met die dekodering daarvan nie. Hierdie soort sirkulariteit is nie so ernstig as wat dit in die geval van sinoniemdefiniense is nie. Die NW se aanbieding van ma wat na moeder verwys word en moeder wat na ma verwys word, is veel ernstiger as bogenoemde. Nog ' $n$ voorbeeld van sulke sirkulariteit in die NW is te vinde by die behandeling van matroos en seeman.

In baie van die gevalle wat met behulp van sinoniemdefiniense hanteer word, kan een sinoniem nie 'n lemma goed genoeg plaas nie en daar moet dan meer van hulle betrek word om die gebruiker tegemoet te kom. So 'n lys sinonieme gee nie ondubbelsinnig leiding oor betekenis nie. Onkundige gebruikers sal sonder meer aanneem dat sulke sinonieme in alle gevalle uitruilbaar is, wat beslis nie die geval is nie. Magay (1988: 174) wys daarop dat 'n reeks sinonieme wat as definisie aangebied word, dikwels vir die gebruiker misleidend kan wees. Dit is ook moeilik om te glo dat reekse sinonieme ten opsigte van konnotasie, denotasie en konteks met mekaar sal ooreenstem. Die doel van sinoniemdefiniëring, naamlik ruimtebesparing en eenvoud van aanbieding, word in die geval van so 'n reeks sinonieme geweld aangedoen en daar kan net sowel van 'n' gewone definisie gebruik gemaak word, veral aangesien die gebruiker waarskynlik meer daarby gaan baat.

Daar moet onderskei word tussen die lysting van 'n reeks sinonieme as definiens en die aanbied van 'n sinoniemparadigma ná ' $n$ definiens. In die eerste geval probeer die opsteller ' $n$ lemma definieer deur van ' $n$ aantal sinonieme gebruik te maak (waarskynlik omdat een sinoniem nie goed genoeg is nie). In die tweede geval word die leksikale betrekkings tussen die definiens en 'n reeks sinonieme geëkspliseer.

Sinoniemdefiniense is nie altyd akkuraat nie en dit kan sake vir die gebruiker bemoeilik. As voorbeeld dien die geval mobiel soos wat die NW dit aanbied: "beweeglik, beweegbaar". Dit is die eerste betekenisonderskeiding van mobiel wat die NW aanbied. By beweegbaar word daar geen verklaring gegee nie (dit word onverklaard gegee). As die gebruiker beweeglik naslaan, word hy met vyf betekenisonderskeidings gekonfronteer en daar word geen leiding gegee oor watter van hierdie onderskeidings by mobiel aansluit nie.

Die ervare gebruiker sal waarskynlik aanvoel dat die eerste betekenisonderskeiding wat aangegee word, naamlik "wat beweging toelaat; beweegbaar", die betekenis is wat sinoniem is met mobiel, maar vir onervare gebruikers is so 'n aanbiedingwyse nie ideaal nie. ' $n$ Eenvoudige definiens wat by mobiel gegee kan word, en wat gebruikers onder geen illusie ten opsigte van die betekenis laat nie, is die volgende: "wat maklik beweeg of beweeg kan word".

Nog ' $n$ voorbeeld wat aansluit by dié van mobiel, is dié van monotoon. In die NW en HAT word monotoon met eentonig verklaar. Omdat eentonig die bykomende betekenisonderskeiding het van "vervelend", en daar in die handwoordeboeke nie leiding gegee word oor die betekenisaspek van eentonig waar- 
op monotoon slaan nie, kan daar eerder ' $n$ eenvoudige definiens by monotoon aangebied word: "op een toon of toonhoogte; sonder om die toon af te wissel".

Sinoniemdefiniense laat ook ruimte vir foutiewe gegewens om deur te glip. Die geval maermerrie soos deur die NW aangebied, kan in hierdie verband vermeld word. By maermerrie word na skeenbeen verwys maar die gebruiker raak nie daar geholpe nie aangesien by skeenbeen weer na tibia verwys word. By tibia 1 word die volgende definiens aangebied: "grootste middelbeen van die onderbeen van ' $n$ werweldier; skeenbeen". Dit is feitelik korrek dat 'n mens se maermerrie die skeenbeen of tibia is, maar by die definiens van tibia (waarna by maermerrie met ' $n$ ompad verwys is) word daar melding gemaak van werweldiere, met ander woorde dit is volgens die NW moontlik dat diere ook maermerries kan hê, maar dit is te betwyfel of daar buite menslike verband na maermerries verwys word.

Nog 'n probleem wat by sommige woordeboeke voorkom, is dat sekere lemmas met 'n sinoniemdefiniens gedefinieer word, maar die sinoniem waarna verwys word, dan nie verklaar word nie. In die NW word byvoorbeeld na fineerhout verwys as beleghout, maar laasgenoemde word nie gedefinieer nie. By majeur word verwys na groottertstoonsoort, maar dit word ook nie verklaar nie. Ook die HAT maak hom hieraan skuldig: by mineraal II word verwys na delfstofhoudend, maar dit word nie verklaar nie.

'n Probleem wat ook soms by sinoniemdefiniense voorkom, is verkeerde verwysing in die geval waar die sinonieme woord wisselvorme het. Om dié probleem te illustreer, kan daar gewys word op die hantering deur die NW van horingstof. Dié term word na keratine verwys, maar die onoplettende gebruiker sal dié term dalk nie opspoor nie omdat die inskrywing onder keratien is. Keratine (en seratien) word wel ook naas keratien aangegee, maar daar is geen rede hoekom horingstof nie direk na keratien verwys is nie aangesien dit alfabeties voor keratine is en daar boonop voorkeur aan die ien-skryfwyse (bo die ineskryfwyse) gegee word.

\subsubsection{Die ideale posisie}

Die ideaal ten opsigte van sinoniemdefiniëring is dat die kruisverwysingsisteem die gebruiker so tegemoet moet kom dat hy geen probleme sal hê met die opspoor en verstaan van die sinoniem waarna hy verwys word nie. By die definiendum wat deur middel van 'n sinoniem verklaar word, word die gebruiker na 'n ander definiendum verwys. In die geval van verskeie polisemiese waardes behoort daar na 'n bepaalde betekenisonderskeiding verwys te word. By die sinoniemdefiniendum moet die verwysde definiendum dan volledig verklaar word.

In woordeboeke behoort gestreef te word na die gebruik van absolute sinonieme in sinoniemdefinisies. Absolute sinonieme kom egter selde voor. Twee sinonieme soos garansie en waarborg stem byvoorbeeld (onder andere) nie ten opsigte van toepassingsomvang ooreen nie. Garansie is minder gebruiklik 
as waarborg. As garansie na waarborg verwys word, behoort die verskil in gebruikstatus deur ' $n$ etiket uitgewys te word. In dié geval kan 'n minder gebruikliketiket by garansie oorweeg word.

Waar daar twyfel oor die sinonimiteit van twee definiendums bestaan, kan afsonderlike definiense eerder gemaak word. In die geval van die NW se hantering van blikaspaai is daar ' $n$ voorbeeld van twyfelagtige sinonimiteit. Die NW bied wegkruipertjie as sinoniemdefiniens van blikaspaai aan, maar die twee kinderspeletjies is nie presies dieselfde nie. Die NW se hantering daarvan is dus nie honderd persent akkuraat nie.

\subsection{Sirkel- en deskriptiewe definisies}

Volgens Gouws (1989: 117) kom sirkeldefiniëring voor wanneer die definiens 'n deel van die definiendum, of ' $n$ afleiding of grondwoord daarvan bevat. Hierdie soort definiëring kan dus net slaag as daar 'n volledige definiens van die deel van die definiendum, die afleiding of grondwoord daarvan gegee word. In dié opsig fouteer die NW met kurettasie: "chirurgiese skraping, verwydering; bewerking d.m.v. " $n$ kuret". In hierdie geval is kuret die grondwoord, maar dit word nie in die NW verklaar nie.

Die sirkeldefinisie word hoofsaaklik vanweë ruimteoorwegings aangebied. In die HAT word feminis byvoorbeeld in terme van feminisme gedefinieer: "Voorstander van die feminisme". Feminisme word dan volledig gedefinieer: "Strewe na gelyke regte vir vrou en man". Die NW gee feminis onverklaard en net feminisme word verklaar.

Gouws (1989: 114) wys ook op deskriptiewe definisies waar die betekenis van die definiendum aangedui word sonder dat die betekenisverhoudinge wat die definiendum met ander leksikale items kan hê, aan bod gestel word. So 'n definiens is dus ' $n$ onafhanklike eenheid waarin die betekenisverklaring wat aangebied word, nie op enigiets anders steun nie.

Dié soort definisie kan baie gebruik word in 'n woordeboek wat arm is aan makrostruktuurelemente. Indien feminisme nie in 'n kleiner woordeboek verklaar word nie, en feminis wel, is 'n deskriptiewe definisie die aangewese uitweg: "iemand wat ' $n$ voorstander daarvan is dat vroue dieselfde geleenthede en regte as mans moet hê".

\section{Definiëringskriteria}

\subsection{Inleidend}

Aangesien definiense in ' $n$ belangrike mate die gehalte van ' $n$ woordeboek bepaal, is dit nodig om kennis te neem van dié aspekte van definiëring wat goeie woordeboekdefiniense tot gevolg het. 
Een van die kriteria wat Arnold (1980: 73) gebruik in die beoordeling van 'n woordeboek, is die kwalitatiewe faktor, en een van die vereistes wat ten opsigte van kwaliteit gestel is, is volledige, akkurate, kort, helder en kontemporêre definiense. 'n Woordeboek wat sulke definiense aanbied, is dus kwalitatief op 'n hoër vlak as 'n woordeboek wat oortree ten opsigte van hierdie kriteria. Gates (1986: 84) en Heliel (1987: 144) sluit by Arnold aan as hulle aandui dat 'n goeie definiens akkuraat, duidelik en bondig moet wees. Gates wys daarop dat in definiens toepaslik na styl en inhoud moet wees vir die uiteindelike gebruiker. Die gebruiker en veral ook die wete wie die gebruiker is, word hier weer sentraal geplaas.

Hierbo is genoem dat definiense volledig, akkuraat, kort en helder moet wees en in die praktyk beteken dit die volgende: 'n definiens is volledig as dit die werklik tersaaklike inligting volledig aanbied sonder om noodsaaklike besonderhede te verswyg. Dit is akkuraat as dit ' $n$ lemma semanties presies en ondubbelsinnig vir die gebruiker kan plaas. Dit is kort wanneer onnodige besonderhede nie vermeld word nie en net die semantiese essensie aangebied word en dit is helder as dit aangebied word in 'n taal wat die gebruiker verstaan. Kontemporêre definiense is dié wat voldoen aan die eise van die tyd waarin die woordeboek geskryf word.

As daar gesê word dat 'n definiens aan die eise van die tyd moet voldoen, word daar nie gesuggereer dat so 'n definiens tydsgebonde moet wees nie. Dit is juis definiense wat in ' $n$ sekere sin tydloos is wat beter standhou as ander. Sommige definiense moet laat blyk dat die tydsfaktor belangrik is. As die lemma krygsmakker byvoorbeeld gedefinieer word, moet die definiens blyke gee daarvan dat dit gaan om 'n makker wat saam in 'n oorlog was of saam in 'n oorlog is. In die WAT word hierdie inligting aangebied: "Makker, kameraad wat saam in 'n oorlog, kryg betrokke is (was)". Die definiens kan egter eenvoudiger (en steeds tydloos) gestel word sonder om enige onakkuraathede te bevat: "Makker in 'n oorlog".

Deur spesifieke tydsverwante aspekte in 'n definiens in te bou, ontstaan die moontlikheid dat dit vinnig kan verouder. Die definiens wat egter vir die gebruiker anachronisties voel, is waarskynlik nie aangepas by die tyd nie, en 'n gebruiker wat 'n ou woordeboek raadpleeg, sal dit dan waarskynlik ook so ervaar. Die leksikograaf kan baie doen om te sorg dat sy woordeboek nie vinnig verouder nie.

\subsection{Volledigheid}

\subsubsection{Inleidend}

'n Woordeboekopsteller kan ten opsigte van die definiense wat hy aanbied, op ' $n$ hele paar maniere fouteer. Rondom die volledigheid van definiense kan op twee maniere gefouteer word: deur óf te volledig óf onvolledig aan te bied. 
Dagenais (1984: 62), Hulbert (1955: 69), Heliel (1987: 134). en Petöfi (1976: 28) vermeld die beginsel van adekwaatheid ten opsigte van definiense. Daarmee bedoel hulle dat ' $n$ adekwate definiens alles wat nodig is, moet bevat om die betrokke lemma uniek te definieer, sodat daardie lemma van alle ander onderskei word. Die semantiese essensie van die lemma moet gegee word en dit moet geskied sonder dat daar onnodige inligting aangebied word.

Landau (1984: 121, 131) wys ook daarop dat die definiens die essensie van dit wat gedefinieer word, moet vasvang. Volgens hom moet die lemma so gedefinieer word dat die vraag: "wat is dit?" onmiddellik beantwoord kan word. As die woordeboek nie genoegsame inligting onmiddellik kan verskaf nie, slaag hy nie in sy doel nie. Baie woordeboekopstellers fouteer hier omdat die saak en die woord verwar word. Volgens Landau moet die belangrikste aspek van die definiens dus eerste kom en dit wat insidenteel is, later. Dit is natuurlik te bevraagteken of insidentele gegewens in ' $n$ leksikografiese definisie tuishoort.

\subsubsection{Onvolledigheid}

Handwoordeboeke maak hulle meermale skuldig aan onvolledige definiense wat oneksplisiet of nie genoegsaam verklaar is nie. Die lemma muis wat deur die NW bloot verklaar word as " $n$ klein knaagdiertjie", is tipies van die onadekwate definiëring wat meermale in handwoordeboeke voorkom. So 'n definiens onderskei nie ' $n$ muis van so iets soos byvoorbeeld 'n marmot wat ook 'n klein knaagdier is nie.

Nog 'n voorbeeld van 'n definiens wat meer inligting benodig, is dié van mandaryn soos aangebied deur die NW en HAT. Die NW bied die volgende aan: "nartjie" (by betekenis 2), terwyl die HAT aanbied: "Soort nartjie; Citrus reticulata" (by mandaryn ${ }^{2}$ ). Meer inligting behoort verskaf te word as dié van die twee handwoordeboeke.

Ook by markies, marmot en marsbanker is die definiense van die NW onvolledig. By markies word aangebied "adellike titel; markgraaf", by marmot "mak knaagdiertjie" en by marsbanker "soort seevis". Eksplisieter definiense wat gegee kan word, is die volgende: " $n$ edelman wat tussen ' $n$ hertog en 'n graaf in rang is"; "'n mak knaagdier, bietjie groter as 'n eekhoring, en met 'n reguit stert" en '" $n$ vis met ' $n$ blou-groen bolyf en 'n silwer onderlyf wat veral aan die Weskus voorkom".

Die hantering van die NW en HAT van die lemma naelskraap kan 'n onvolledige aanpakwyse illustreer. Die definiens wat in die NW daarvoor aangebied word, is die volgende: "net-net, met min speling". Die.HAT bied weer die volgende aan: "Hittete, amper, byna". In die geval van die NW se definiens word daar nie voorsiening gemaak vir naelskraap in die betekenis van "amper" of "byna" soos in die sin dit was so naelskraap of die motor het omgeslaan nie. Die HAT maak weer nie voorsiening vir die betekenis van naelskraap soos dit in naelskraap aan die dood ontkom voorkom nie. In dié geval beteken naelskraap 
natuurlik "net-net". Ironies genoeg word bogenoemde frase in die HAT gebruik, maar die definiens maak nie voorsiening vir die frase nie. Vergelyk byvoorbeeld wat gekry sal word as die vervangingsbeginsel toegepas moet word in dié frase: Hulle het hittete, amper, byna aan die dood ontkom. As die HAT "net-net" as bykomende definiens van naelskraap aangebied het, dan het die vlag die hele lading gedek.

Nog 'n geval wat deur die HAT en NW op onvolledige wyse gehanteer word, is dié van middellyn. Al betekenis wat deur albei woordeboeke hier aangedui word, is die lyn wat ' $n$ sirkel in twee gelyke dele verdeel. Die meeste mense wat hieroor genader is, het aangedui dat ' $n$ middellyn vir hulle die lyn is wat ' $n$ sportveld in twee gelyke dele verdeel. ' $n$ Woordeboek behoort so verteenwoordigend te definieer dat daar geen verwarring oor middellyn is nie: "lyn wat iets in twee gelyke dele verdeel, byvoorbeeld 'n sirkel of 'n sportveld". Ook die lemma misvat word deur die HAT net eenduidig verklaar (die NW bied dit nie aan nie), terwyl die betekenisonderskeiding wat die HAT weglaat, vir die meeste mense die algemeenste is. Volgens die HAT is misvat die volgende: "Verkeerd opvat, begryp". Twee betekenisonderskeidings kan aangebied word: "om nie raak te vat nie" en "om verkeerd op te vat of te verstaan".

By die lemma lugdiens kan 'n vollediger definiens aangebied word as dié van die HAT (die NW het die lemma nie opgeneem nie). Die HAT se definiens van lugdiens is die volgende: "Diens met vliegtuie; vliegdiens". Die volgende kan aangebied word: "'n gereelde diens van lugvervoer" (wat analoog is aan busdiens), en "'n maatskappy wat so 'n diens lewer".

\subsubsection{Oorolledigheid}

Die keerkant van onvolledige definiense is oorvolledige definiense waarin onnodige saakbesonderhede aangegee word. Die aanbied van sulke ekstralinguistiese gegewens in 'n woordeboek is swak leksikografiese praktyk, en dit veroorsaak dat definiense moeiliker verstaanbaar is omdat dit moeilik is om te onderskei tussen gegewens wat werklik ter sake is en dit wat nie ter sake is nie. Die verwarring tussen woord en saak kan allerlei interessante maar rampspoedige gevolge hê (Odendal 1979: 30, 32).

As konnotasies en assosiasies sowel as betekenistoepassings en saakbesonderhede toegelaat word om deel van die betekenisaanbieding te word, lei dit dikwels tot te veel fyn betekenisonderskeidings wat versplintering van betekenis in die hand werk. Op dié wyse word die betekenisoordrag verswaar. Te veel betekenisonderskeidings getuig van 'n vlak semantiese analise.

Alle assosiasies en konnotasies, behalwe dié wat gemeenskaplik is (wat dus eintlik al denotasie is) moet in definiense vermy word. In die WAT is daar heelwat definiense met die bewoording dikw. $m / d$ bygedagte aan/van. Die inligting wat dan gegee word, is dikwels konnotasies, en nie deel van die werklike betekenis van die lemma nie. Alhoewel 'n woordeboekgebruiker daarop geregtig is om semantiese inligting én inligting oor die gebruik van 'n woord te kry, 
moet daar 'n onderskeid gemaak word tussen leksikale betekenis en buitelinguistiese gesuggereerde of geassosieerde "betekenisonderskeidings". Die onvoldoende onderskeid tussen linguistiese en buite-linguistiese eienskappe kan onder andere meer polisemiese onderskeidings suggereer as waaroor ' $n$ bepaalde woord werklik beskik. Benewens die feit dat die betekenisoordrag verswaar word, lei dit ook tot ensiklopedisiteit. In 'n definiens moet alleen linguisties gemotiveerde inligting aangebied word. Kontekstuele getuienis moet in voorbeeldsinne tereg kom.

Dit is nie verkeerd van die leksikograaf om te streef na die grootste mate van volledigheid en korrektheid in die hantering van sy definiense nie, maar omdat die gemiddelde taalgebruiker ' $n$ woord kan gebruik sonder om al die eienskappe van die saak wat daarmee verband hou, te ken, en omdat die leksikograaf in elk geval nie al die saakbesonderhede wat met 'n woord verband hou, kan gee nie, het dit geen sin om 'n ensiklopediese werkwyse te volg nie. Katz (1972: 60) beweer die volgende: "Meaning must be an abstraction from the variable features of the things referred to by a term: the meaning of a word must represent only the invariant features by virtue of which something is a thing, situation, activity, event or whatever of a given type. Otherwise no word could ever be used again with the same meaning with which it is used at any one time, since there is always some difference in what is referred to from one time to the next."

Dit is moontlik om ' $n$ woord op 'n volledige en korrekte wyse vir die gebruiker duidelik te maak sonder om saakbesonderhede daaroor te verstrek. Die voorbeeld van branderplank wat hieronder aan bod kom, kan dit illustreer.

Een van die slaggate waarin leksikograwe dikwels trap, is dié van oorspesifieke en saakgerigte definiëring. Vergelyk in dié verband die WAT se definiens van branderplank: "Lang smal plank, van voor effens gebuig, deur strandgaste vir branderry gebruik". Omdat spesifieke saakbesonderhede hier vermeld is, en nie die funksie en tipiese gebruik nie, het die definiens verouder. 'n Branderplank is naamlik nie meer lank en smal nie, maar eerder kort en breed. Die voorpunt is nie effens gebuig nie, maar gepunt. Die saakbesonderhede van ' $n$ branderplank het dus intussen verander, en dit kan weer verander. ' $n$ Branderplank word ook nie net deur strandgaste gebruik nie. In die geval van branderplank word daar ook gefouteer deur die samestelling uit die som van sy komponente te verklaar. ' $n$ Branderplank is meer as net ' $n$ plank. Branderplank kan gedefinieer word as "vaartuig waarmee branders in die staande posisie gery word".

Om té analities te definieer, is gevaarlik, want dit laat die deur vir die opname van saakbesonderhede wyd oop, en baie leksikograwe fouteer dan ook in dié verband deur te ensiklopedies te definieer. Hanks (1979: 33) wys op dié gevaar wanneer hy 'n vergelyking tref tussen die hanteringswyse van twee woordeboeke van die lemma "door" waar die een definiens sintakties oorbelas is terwyl die ander een 'n goeie balans tref tussen "volheid" en leesbaarheid. Genoeg referensiële inligting moet vir die gebruiker gegee word om die defi- 
niens maklik te snap, maar nie alle inligting hoef gegee te word nie. Nie 'n volle analise nie, maar eerder 'n tipering is dikwels genoegsaam. Hiermee word een van die belangrikste kriteria van 'n goeie definiens aangedui: dit moet die mees tipiese kenmerke van gebruik en konteks aanbied sonder om té analities te wees. Die definiens moet volledig wees sonder om oorvolledig te wees.

'n Metode wat met vrug aangewend kan word om saakbesonderhede te beperk, is dié van komponensiële analise. Alhoewel daar steeds in ' $n$ analitiese definiens saakbesonderhede genoem word, kan daar met behulp van dié metode slegs die noodsaaklikste(s) vermeld word om 'n subordinaat van ander te onderskei wat onder dieselfde superordinaat kan ressorteer.

As voorbeeld sou die lemma motorfiets kon dien. 'n Kort definiens daarvan sou die volgende kon wees: "tweewielige kragaangedrewe voertuig, gewoonlik groter en kragtiger as 'n bromponie". Voertuig is hier 'n gemeenskaplike betekeniskomponent met byvoorbeeld fiets, bromponie, skip, trein, vliegtuig, motor, ensovoorts. Tweewielig is ' $\mathrm{n}$ diagnostiese komponent wat motorfiets, bromponie en fiets onderskei van ander vervoermiddels. Om motorfiets van fiets en bromponie te onderskei, is daar verdere diagnostiese komponente nodig. Kragaangedrewe onderskei bromponie en motorfiets van fiets, en groter en kragtiger onderskei motorfiets van bromponie.

\subsubsection{Oorspesifisering}

Woolf (1973: 256) wys daarop dat definiense té spesifiek kan wees. Die gevaar van oorspesifisering is volgens Woolf dat definiense onakkuraat kan wees of vinnig kan verouder. In ons tegnokratiese eeu verander dinge baie vinnig en dit waarvan 'n voorwerp gemaak is, kan môre of oormôre byvoorbeeld deur 'n ruimte-eeuse materiaal vervang word. Dit is daarom noodsaaklik dat leksikograwe saakbesonderhede wat wel nodig is, so sal aanbied dat die moontlikheid van verandering nie uitgesluit word nie en dat hulle die saakbesonderhede wat nie absoluut nodig is nie, uit hulle woordeboeke moet weer.

As die leksikograaf wat kruk (die soort waarmee invalides voortbeweeg) 'n hele aantal jare gelede moes definieer byvoorbeeld gespesifiseer het dat ' $n$ kruk van hout is, sou sy definiens net vir 'n paar jaar op akkuraatheid aanspraak kon maak, want krukke word deesdae veral van metaal gemaak. Die spesifikasie oor waarvan 'n kruk gemaak is, is in elk geval onnodig, want nie die materiaal waarvan dit gemaak is nie, maar die funksie daarvan is werklik ter sake. Die leksikograaf moet probeer om 'n sekere tydloosheid in sy definiens in te bou, en dit kan dikwels bereik word deur nie te veel te spesifiseer nie, dit wil sê deur saakbesonderhede wat nie werklik bydra tot die identifisering en plasing van die saak wat gedefinieer word nie, weg te laat. Dit sal die leksikograaf ook baat om op hoogte te bly van tegnologiese ontwikkeling. Dit sal verseker dat hy nie so maklik ontspoor in sy betekenisaanbieding nie. Alhoewel geredeneer kan word dat betekenisaanbieding nie deur saakontwikkeling geraak behoort 
te word nie, kan dit tog voorkom dat ' $n$ fundamentele verandering van 'n saak die betekenisaanbieding daarvan kan beïnvloed.

'n Geval waar té spesifiek gedefinieer word, en waar dié definiens nie alle moontlikhede dek nie, is die definiens van bajonetsluiting in die NW: "soort koppeling waarby ' $n$ stuk met pennetjies in ' $n$ stuk met twee gleuwe gedraai word". Dié definiens is sekerlik van toepassing op die bajonetsluiting tussen ' $n$ gloeilamp en die lamp waarin dit bevestig word, maar dit is nie van toepassing op die bajonetsluiting tussen kameras en kameralense nie. 'n Beter definiens sou die volgende wees: '"n stewige koppeling tussen twee silindriese voorwerpe wat bewerkstellig word deurdat die uitsteeksels van die een in die gleuwe van die ander sluit".

Nog 'n geval waar daar te spesifiek gedefinieer word, is die NW se hantering van maan: "die aarde se satelliet". Ook die HAT se definiens is in hierdie geval te spesifiek. Daar is ander mane in die ruimte behalwe die een wat om die aarde wentel, en vir dié moontlikheid moet toegelaat word: "n kleiner hemelliggaam wat om 'n groter een draai, veral die een wat om die aarde draai".

'n Definiens is eintlik 'n kompromie tussen spesifieke akkuraatheid en die mate van insluitbaarheid. Betekenis word geabstraheer uit 'n groot aantal gebruiksmoontlikhede en die leksikograaf moet daarom 'n balans vind deur ' $n$ definiens so spesifiek as moontlik aan te bied terwyl dit versoenbaar is met ' $n$ realistiese breë betekenisomvang (Landau 1984: 148). Volgens Zgusta (1971: 253) moet die definiens algemeen genoeg wees om al die moontlikhede te impliseer sonder dat almal eksplisiet genoem hoef te word. Dit moet spesifiek wees sonder om té spesifiek te wees. In die WAT word daar dikwels te veel gespesifiseer. Vergelyk die volgende definiens van kontakspoor: "By ' $n$ elektriese trein, veral 'n moltrein - spoor, metaalstaaf tussen of langs die spoorstawe en ewewydig met hulle, op of naby die grondvlak op isolatore bevestig, wat stroom a/d trein lewer d.m.v. 'n kontakskaats". Die volgende definisie is meer veralgemenend en tiperend: "Spoor wat elektriese stroom lewer aan vervoermiddels".

In die meerderheid gevalle is oorspesifieke definiense geneig om ensiklopedies te wees, of te grens aan die ensiklopediese.

\subsection{Helderheid}

\subsubsection{Inleidend}

In 'n ondersoek wat gemaak is oor die sosiale impak van woordeboeke in die Verenigde Koninkryk, het Quirk $(1973: 86,87)$ gevind dat daar veral ten opsigte van definiense heelwat verbeteringe voorgestel is. Van die voorstelle wat gemaak is, het laat blyk dat daar veral 'n groot behoefte aan helderheid was. Die respondente het gevoel dat definiense minder gekompliseer of onhelder, herhalend, gedetailleer en gefragmenteer behoort te wees. 
Die kriterium van helderheid bring mee dat die leksikograaf na eenvoud in sy definiense moet streef. Woolf (1973: 257) wys daarop dat die leksikograaf selfs gespesialiseerde terme so moet definieer dat dit nie net deur deskundiges verstaan kan word nie, maar ook deur leke.

Dit is geen geringe taak om eenvoudig te werk te gaan in die definiëring van ingewikkelde konsepte nie, en Zgusta (1971: 255) noem dat tegniese terme van die moeilikste dinge is om te definieer. Die definiense daarvan moet volgens hom allereers korrek wees, die objekte moet korrek beskryf word en die algemeen aanvaarde idee van wat die objekte is, moet gereflekteer word. Zgusta noem ook dat leksikale eenhede wat plante en diere moet beskryf, probleme veroorsaak wat met dié van tegniese terme ooreenkom, aangesien hulle (veral in kleiner woordeboeke) in algemene terme beskryf moet word. Wat Zgusta hier sê, is sekerlik waar, maar dit is nie alleen tegniese terme wat moeilik is om te definieer nie. Dit kom dikwels voor dat ander, gewoner lemmas veel moeliker is om te definieer as "eksotiese" lemmas.

Evans (1969: 217) wys op dié idiosinkrasie rondom definiëring as hy noem dat dit soms maklik is om iets wat uniek, snaaks of nuut is te beskryf, maar dat dit dikwels moeilik is om die gewone te definieer omdat juis die gewoonheid van iets dikwels vereis dat ongewone terme gebruik moet word om dit deeglik of genoegsaam te definieer. Hanks (1979:34) sluit daarby aan as hy beweer dat selfs alledaagse woorde die leksikograaf moeilikheid kan gee. Miskien kon hy bygevoeg het dat dit veral die alledaagse woorde is wat moeite gee. Die kriterium wat ook in dié geval geld, is duidelik: alle lemmas, eenvoudig of ingewikkeld, moet vir die teikengebruiker so helder en eenvoudig as wat dit maar kan gedefinieer word. Die vermoë om iets helder te formuleer, moet deel wees van 'n woordeboekopsteller se mondering.

\subsubsection{Verstaanbaarheid}

Dit lyk nodig dat volledigheid en akkuraatheid van definiense ook met helderheid getemper moet word, anders kan daar 'n situasie ontstaan waar die aangebode definiens baie volledig en akkuraat gedefinieer is, maar nie verstaanbaar genoeg nie. In 'n artikel oor leksikografie en die pedagogiese implikasies daarvan, beklemtoon Cowie (1980: 205) die belangrikheid van die balans tussen volledige en akkurate behandeling aan die een kant, en maklike verstaanbaarheid en gebruik aan die ander kant van definiense.

Baie leksikoloë plaas ' $n$ hoër premie op helderheid as op enigiets anders, selfs leksikografiese juistheid. Dat helderheid net so belangrik is as akkuraatheid, word onderskryf deur Hanks (1979: 35) wat daarop wys dat sekere definiense absoluut korrek aangebied word, maar op 'n onverstaanbare wyse. Aangesien die meeste gebruikers van woordeboeke waarskynlik ten opsigte van baie van die definiense wat aangebied word leke is, kan die leksikograaf volgens Hanks ' $n$ minder presiese definiens aanbied wat meer verstaanbaar is 
eerder as 'n presiese definiens wat onverstaanbaar is. Die ideaal sal natuurlik wees om presies en eenvoudig te werk te gaan, en dit is nie onmoontlik nie.

\subsubsection{Implikasies van 'n helder aanbieding}

'n Helder formulering vra van die leksikograaf 'n doelbewuste poging om sy gebruikers tegemoet te kom by die aanbieding van die definiense in sy woordeboek. Volgens Eksteen (1965: 151-154) kom dit daarop neer dat die leksikograaf alle slordighede, byvoorbeeld ten opsigte van die sinsbou, spelling en woordorde, uit sy produk moet weer. Hy moet ook onnodige woorde weglaat en presies te werk gaan in sy formulering. 'n Onvermoë om helder te formuleer, het ' $n$ ingewikkelde definiens tot gevolg, en definiense word juis aangebied om iets vir 'n gebruiker te ontsluit, en nie om dit te verduister nie.

Neubauer (1984: 117) sluit aan by die idee dat definiense in eenvoudige en helder taal moet wees en hy wys op 'n paar dinge wat gebruikers (in dié geval vreemdetaalgebruikers) van monolinguale woordeboeke ontevrede maak by die raadpleeg daarvan: "Some of the reasons for this kind of negative attitude towards monolingual dictionaries by users consist of low-level circularity and of using words for the explanations of a headword which are more difficult than the words to be explained. An established strategy for avoiding these particular pitfalls ... consists of controlling the vocabulary used in the explanations."

In hierdie opsig sal dit help as die gekontroleerde woordeskat waarvan Neubauer praat, sodanig is dat iets wat vir die gebruikers vreemd is, vir hulle beskryf kan word in terme wat vir hulle bekend is. Quine (1973: 249) en Wierzbicka (1985: 337) beweer dan ook dat dit die doel van 'n verklarende woordeboek is om onbekende woorde vir die gebruiker bekend te maak deur elke woord te definieer met behulp van woorde wat 'n groter frekwensie het, en wat dus meer bekend is. Definiense moet in natuurlike taal aangebied word om betekenisvol te wees (Wierzbicka 1985: 336).

Die woordeskat wat in definiense gebruik word, moet egter nie lukraak gekies word nie, omdat dit tot probleme soos 'n sirkulêre aanbięding kan lei. Woorde wat in definiense gebruik word, kan nie op 'n ad hoc-wyse gekies word nie. Die definiëring van komplekse konsepte in terme van eenvoudiger konsepte is die enigste manier waarop insig in betekenis verkry kan word (Wierzbicka 1985: 337, Landau 1984: 134, Kipfer 1984: 65 en Leech 1981: 206, 207). Om onbekende terme deur middel van meer bekende terme te beskryf, word ' $n$ metataal benodig en daarvoor moet die leksikograaf volgens Wierzbicka (1985: 337) bereid wees om deur heelwat definiense te werk.

Die beginsel dat elke woord wat in 'n definiens gebruik word, elders gedefinieer moet word, word dikwels deur woordeboeke geïgnoreer, en dit dra by tot onheldere definiense. Die leser kan met reg verwag om ' $n$ woord wat in ' $n$ definiens gebruik word en wat hy nie verstaan nie, elders op te spoor. As 'n gebruiker ' $n$ woord in ' $n$ definiens van ' $n$ woordeboek nie verstaan nie, is dit ' $n$ 
aanklag teen die metataal van die woordeboek, want dit moet voorsiening maak vir 'n eenvoudige en akkurate "taal" waarin gedefinieer kan word. Zgusta (1971: 257) beweer ook dat die woorde waarmee gedefinieer word, in die woordeboek moet verskyn. Die definiens moet volgens hom ook nie woorde bevat wat moeiliker is as die woord wat gedefinieer word nie en daar mag ook nie argaïese, dialek- of vulgêre woorde daarin gebruik word nie. Die definiendum moet ook nie in die definiens gebruik word nie (Zgusta 1971: 257, Landau 1984: 121).

Hierdie laaste opmerking van Zgusta en Landau word deur verskeie ander leksikoloë ondersteun, en tog maak Collins se COBUILD Essential English Dictionary met groot vrug van die definiendum as onderwerpsnaamwoordstuk in die definiens gebruik. Die definiense wat aangebied word, bestaan ook nie almal uit een sin nie. Dit lyk wenslik dat leksikografiese konvensies nie so star moet wees dat konvensie ten koste van bruikbaarheid moet geld nie. ' $n$ Voorbeeld van COBUILD se definisie-aanbieding is die hantering van popper: "A popper is a device for fastening clothes. It consists of two pieces of plastic or metal, one with a small lump on it and the other with a small hole in it. You press the two bits together in order to fasten the popper." Dit is egter " $n$ vraag of bogenoemde definiens nie langs konvensionele weë korter en net so verstaanbaar aangebied kan word nie.

In kleiner woordeboeke is dit dikwels moeilik om al die woorde wat in die definiense gebruik word, ook te definieer. Dié reël word soms uit noodsaak verbreek omdat die leksikograaf oorweging moet gee aan ruimtebesparing. Een van die belangrikste faktore wat op die spel kom by definiëring is juis die gebrek aan ruimte. Dit is dikwels 'n beperkende faktor, maar die gebrek aan ruimte dwing die leksikograaf hopelik tot 'n bondige maar akkurate definiens - en dit is goeie leksikografiese praktyk. As die leksikograaf nie ál die woorde wat in sy definiense gebruik word, kan opneem nie (vanweë ruimteoorwegings) dan moet hy in elk geval baie seker maak dat die taal van sy definiense so eenvoudig as moontlik is.

\subsubsection{Implikasies van omslagtigheid}

Omdat 'n heldere uiteensetting deur 'n uitvoerige en lang aanbieding gekniehalter kan word (die kanse dat 'n omslagtige definiens helder gaan wees, is baie skraal), gaan die kriterium van helderheid saam met bondigheid.

Van Schalkwyk en Kroes (1979: 103) en Eksteen (1965: 154) bied inderdaad die twee kriteria naas mekaar aan. Die gebruiker kan die beste gedien word deur 'n kort en helder definiens en daarom moet daar ter wille van helderheid voorkeur aan die kortste definiens gegee word, behalwe as dit nie die betekenis van 'n woord duidelik weergee nie. Landau (1984: 137) noem ook dat definiense woordekonomies moet wees. Volgens hom bestaan die kuns van definieer nie slegs in die vermoë om woorde te analiseer en te verstaan nie maar ook in 
die pittige en kernagtige weergee van die betekenis daarvan. Elke definiens moet dus die meeste sê met die minste aantal woorde.

Omdat so baie gegewens in 'n woordeboek hanteer moet word, is dit wenslik dat die verklarings wat aangebied word, so bondig is as wat dit maar kan. In handwoordeboeke is bondigheid 'n voorvereiste, want ruimteoorwegings laat nie 'breedsprakigheid' toe nie. Bondigheid geld egter nie slegs vir die kleiner woordeboeke nie; dit kan met vrug in groter verklarende woordeboeke gebruik word. As die leksikograaf by die definiëring van ' $n$ woord dit in gedagte hou dat hy net daardie onderskeidende kenmerke hoef aan te bied wat so ' $n$ woord van alle ander (van byvoorbeeld dieselfde klas) onderskei, sal daar waarskynlik vanselfsprekend woordekonomies te werk gegaan word. ' $\mathrm{O}$ Omslagtige definiens dra waarskynlik swaar aan ekstralinguistiese gegewens.

\subsubsection{Verkeerde leksikografiese aannames}

Omdat daar dikwels onheldere definiense in handwoordeboeke voorkom, lyk dit of daar eintlik 'n veronderstelling gemaak word dat die gebruikers daarvan altyd ervare is.

' $n$ Voorbeeld van so 'n handwoordeboekdefiniens waarmee selfs 'n ervare gebruiker probleme sal hê, is dié van mise-en-scène in die NW: "toneelinrigting, -skikking". Nóg toneelinrigting nóg toneelskikking word in die NW verklaar. 'n Woordeboekskrywer wat aanneem dat sy gebruikers uit die samestellende dele van 'n lemma 'n sinvolle afleiding moet maak soos wat die NW dit heel duidelik in bogenoemde geval van sy gebruikers verwag, maak ongeregverdigde aannames omtrent sy gebruikers.

By die NW word muf verwys na skimmel en witroes. Laasgenoemde word nie verklaar nie en by die tweede betekenis van skimmel word die volgende aangebied: "muwwerigheid wat op ontbindende stof groei". Die gebruiker wat wou weet wat muf is, word nie veel gehelp nie, want as hy nie weet wat muf is nie, sal hy ook nie weet wat muwwerigheid is nie (laasgenoemde word nie verklaar nie).

Dit is moontlik dat leksikograwe definiense helderder vir hulle teikengebruikers kan aanbied as wat sommige handwoordeboeke dit doen. Wat gevra word, is 'n gerigtheid op eenvoud en bondigheid, selfs in die definiëring van die ingewikkeldste konsep.

\subsection{Akkuraatheid}

'n Deel van enige leksikograaf se taak is om aan sy teikengebruikers akkurate inligting in sy definiense te gee. Ongelukkig begaan leksikograwe dikwels foute wat onakkurate definiense tot gevolg het.

Magay (1988: 172) wys daarop dat die aanbied van gebruiksleiding een van die leksikograaf se grootste dilemmas kan wees. By die definiëring van 'n lemma moet die leksikograaf byvoorbeeld kan voorsien dat die woord van toe- 
passing is op sekere dinge en op ander nie. Daar kan byvoorbeeld in die geval van die lemma kragtig gepraat word van 'n kragtige motor, maar nie van kragtige tee nie. Die woord sterk daarenteen, kan ten opsigte van tee gebruik word, maar waarskynlik nie so geredelik ten opsigte van 'n voertuig nie. Die leksikograaf moet probeer om beperkings van woorde wat oënskynlik min of meer dieselfde beteken, reeds in sy definiens te ondervang deur die nodige gebruiksleiding daarin te probeer suggereer. Deur akkuraat te definieer, kan baie van die vaaghede wat soms in definiense voorkom, ondervang word.

By die NW en HAT kom daar soms onakkurate definiense voor omdat sekere noodsaaklike inligting verswyg word en/of doodgewoon foutief is of omdat daar verkeerd geformuleer word. Die NW bied byvoorbeeld die volgende definiens van leeu: "grootste roofdier van die katagtige diere". Dié definiens is twyfelagtig, want sommige tiersoorte is groter as die leeu.

By malaria word in die NW beweer dat die siekte deur 'n muskiet veroorsaak word: "koors van tropiese gebiede wat deur 'n muskiet veroorsaak word", maar dit is onakkuraat; die siekte word deur ' $n$ virus veroorsaak waarvan die draer 'n sekere soort muskiet is. Die definiens kan soos volg lui: "'n koorssiekte wat in tropiese gebiede voorkom en waarvan die draer 'n muskiet is". Die taak van die leksikograaf is egter groter as om net feitelik akkuraat te reflekteer. Hy moet ook die taalwerklikheid reflekteer, en dit sluit aan by mense se persepsies oor malaria. As die meeste mense aanvoel of glo dat malaria deur 'n muskiet veroorsaak word, dan moet die leksikograaf dit so aanbied. In so 'n geval sal daar twee betekenisonderskeidings aangebied kan word; die feitelik korrekte en die perseptueel korrekte. Dit is egter ' $n$ vraag of die twee betekenisonderskeidings op 'n semantiese vlak onderskei kan word.

By maansiek is die definiens wat die NW aanbied, nie akkuraat nie (en gevaarlik dogmaties): "kranksinnig". 'n Definiens wat meer neutraal en feitelik is, is die volgende: "wat ly aan 'n soort senukwaal wat saamval met die fases van die maan". By muskeljaatkat fouteer die NW deur daarna te verwys as 'n soort knaagdier, terwyl dit ' $n$ klein roofdiersoort is wat veral op knaagdiere jag maak.

Die definiense wat die HAT en NW van mensvreter aanbied, is te beperkend en nie algemeen genoeg nie. In albei gevalle word daar slegs vir mense voorsiening gemaak, maar dit kom dikwels voor dat sekere diere in mensvreters ontaard, byvoorbeeld leeus of tiere. Deur akkurater te reflekteer, kan die volgende verkry word: "iemand of iets, byvoorbeeld 'n roofdier, wat mensvleis eet of vreet". Nog 'n definiens van die NW wat nie onderskeidend genoeg is nie, en dus nie akkuraat genoeg gedefinieer is nie, is dié van lugskip: "lugvaartuig wat ligter as lug is; zeppelin". Die definiens van die NW maak nie onderskeid tussen 'n lugballon en lugskip nie, want 'n lugballon is ook 'n lugvaartuig wat ligter as lug is. Dié verskil kan ondervang word deur aan te toon dat ' $n$ lugskip aangedryf en beheer word deur enjins terwyl dit nie die geval met 'n lugballon is nie. Dit is ook twyfelagtig of die sinoniem wat deur die NW by 
lugskip aangebied word, naamlik zeppelin, akkuraat is. Alle lugskepe kan nie as zeppelins kwalifiseer nie aangesien slegs die Duitse lugskepe so bekend was.

Twee lemmas wat ook op bedenklike wyse deur die NW hanteer word, en wat myns insiens onakkuraat is, is bloedvergieting en boetiek. By bloedvergieting word die volgende aangebied: "handeling van mensebloed te laat vloei in oorlog, deur moord, ens.". In hierdie geval is die beswaar dat bloedvergieting nie soseer 'n handeling is nie maar dat dit 'n toestand verteenwoordig. Boetiek word gedefinieer as "modieuse winkeltjie, ingestel op jong mense". Of 'n winkel modieus kan wees, is oop vir kritiek, maar boetieks is lankal nie meer "winkeltjies" nie, en die klandisie is nie net jong mense nie.

Om te verseker dat sy definiense akkuraat is, moet die leksikograaf ook sorg dat daar geen dubbelsinnigheid in sy definiense voorkom nie omdat dit gebruikers op dwaalspore kan laat beland. Petöfi (1976: 28) en Landau (1984: 138) wys daarop. Dit kom daarop neer dat ' $n$ woord wat meer as een betekenisonderskeiding het, nie in 'n definiens gebruik moet word nie. In so 'n geval moet die definiens eerder omskryf word, of anders moet die betekenis wat in die bepaalde geval geaktiveer moet word, duidelik uit die konteks kan blyk soos dit in die res van die definiens gesuggereer word. Vergelyk in dié verband die voorbeeld van eentonig onder 2.2.2 (hierbo).

\subsection{Konsekwentheid}

'n Terrein waarop die leksikograaf die gebruiker tegemoet kan kom en wat ook gebruikersvertroue positief beïnvloed, is konsekwentheid en bestendigheid ten opsigte van die aanbieding van definiense. Volgens Kipfer (1984: 69) sal die professionele woordeboekmaker baie klem plaas op groepsdefiniëring en die sorg waarmee verwante terme gedefinieer word. As die leksikograaf byvoorbeeld die term Januarie definieer, dan behoort hy die ander maande van die jaar op dieselfde wyse te hanteer. ' $n$ Goeie woordeboek is daarom konsekwent in die aanbieding van definiense wat 'n soortgelyke wyse van hantering vra.

\subsection{Selfstandigheid}

Dit is ' $n$ ideale situasie as die teikengebruiker by die eerste definiens wat hy raadpleeg, geholpe kan raak (met die uitsondering van poliseme), dit wil sê dit behoort nie nodig te wees om nog definiense te raadpleeg om een betekenis te wete te kom nie.

Landau (1984: 145, 146) kom tot die gevolgtrekking dat elke definiens 'n wêreldje op sy eie moet verteenwoordig. Elke definiens behoort volkome afsonderlik van elke ander definiens te wees en dit moet 'n klein, aparte opstel van sy eie wees wat genoeg leidrade gee ten opsigte van die konteks sodat daar by die gebruiker geen verwarring is omdat ' $n$ vollediger verwysingsraamwerk ontbreek of die woord vir hom totaal vreemd is nie. In 'n woordeboek moet elke definiens in staat wees om op sy eie pote te staan. 
Die NW se aanbieding van metrum is ' $n$ voorbeeld van 'n onselfstandige definiens. By metrum word versmaat as sinoniemdefiniens aangebied, maar in die definiens van versmaat word daar verwys na vote en die onkundige gebruiker sal dus by voet verder moet gaan soek om die definiens van versmaat te verstaan. By voet 6 word verwys na versvoet, maar dit word nie gedefinieer nie.

In ' $n$ poging om die betekenis van metrum te begryp, moes die gebruiker dus deur verskillende definiense werk net om te stuit op iets wat nie verklaar word nie. Dit is nie goeie leksikografiese praktyk nie. Die leksikograaf kan baie probleme van dié aard uitskakel deur selfstandiger te definieer.

\subsection{Objektiwiteit en neutraliteit}

Die opsteller van 'n woordeboek moet pragmaties en objektief te werk gaan. Hierdie werkwyse moet ook neerslag vind in die definiense wat hy aanbied.

Odendal (1978: 65) wys daarop dat die leksikograaf by definiëring aan die eis van objektiwiteit moet voldoen. Dit vra twee dinge van die leksikograaf: hy moet hom nie tussen die woord en die definiens plaas deur dit emosioneel in te kleur nie, en hy moet nie preskriptief te werk gaan nie. Die leksikograaf moet nie 'n definiens emosioneel inkleur nie, maar deskriptiwiteit kan hom in sekere gevalle van betekenisaanbieding probleme verskaf. Dit kan naamlik gebeur dat werklik waargenome taalgebruik die leksikograaf in sy definiensaanbieding verlei.

Die werklik waargenome taalgebruik waarop die leksikograaf sy definiense wil baseer, kan vir hom sekere gemeenskaplike konnotasies suggereer wat in (privaat)gesprekke sonder skade genoem kan word en wat in geskrewe tekste gemotiveerd deurgegee kan word sonder dat dit aanstoot gee, maar wat nie sonder meer in die woordeboek aangebied kan word nie, selfs nie eers met ' $n$ etiket nie. Daar kan maklik na 'n nie-Jood (veral in sy afwesigheid) as 'n Jood verwys word, maar om die konnotasie onderliggend aan daardie gebruik van lood in ' $n$ woordeboek te reflekteer, is om moeilikheid te soek.

In hierdie opsig moet die leksikograaf versigtig (en selfs preskriptief) te werk gaan. Woordeboeke moes in die verlede regstellings maak omdat sekere sensitiewe konnotasies in definiense aangebied is. Die leksikograaf kan hom verweer deur te sê dat hy maar net die gemeenskaplike konnotatiewe wete van die taalgebruikers verwoord het (wat as sodanig reeds denotasies is), maar waar dit andersins goeie leksikografiese praktyk is, kan dit rondom sensitiewe sake teen ' $n$ woordeboek tel as die woordeboek maar net die taalgebruik reflekteer.

Ten opsigte van potensieel emosionele woorde behoort die leksikograaf dus sy neutraliteit te handhaaf. Die leksikograaf moet ook volgens Eksteen (1965: 150) die gebruiksgevalle waarop hy sy definiens gaan baseer, met goeie oordeel en wetenskaplikheid benader. 


\section{Riglyne}

Die volgende riglyne kan in woordeboeke gevolg word vir die verkryging van goeie definiense:

(1) Alle definiense moet op die taalwerklikheid gebaseer word.

(2) Alleen semantiese inligting moet in die definiens aangebied word. Dit vereis dat slegs essensiële inligting en geen insidentele inligting nie, gegee moet word; dat saakbesonderhede, konnotasies, assosiasies en gebruikstoepassings en -leiding in definiense vermy word; dat ' $n$ tipe en die funksionele aanwending eerder as fisiese kenmerke (saakbesonderhede) as onderdele van 'n definiens aangebied word.

(3) Definiense moet tydloos wees, behalwe dié wat historisiteit moet reflekteer.

(4) Definiense moet feitelik korrek wees en ook persepsies van die gebruikers reflekteer.

(5) Definiense moet objektief en neutraal wees, dit wil sê sonder persoonlike vooroordele en nie ideologies, rassisties, religieus of seksisties gelade nie.

(6) Alle definiense moet maklik begrypbaar wees. Dit vereis dat definiense kort en maklik leesbaar moet wees; helder en eenvoudig geformuleer moet wees; sonder sintaktiese vervattings, reekse sinonieme en dubbelsinnige woorde moet wees; 'n metataal moet hê wat aansluit by die laagste geïdentifiseerde gebruikersklas; makliker as die definiendum moet wees; uit woorde bestaan wat elders verklaar word; nie sirkelvormig moet wees nie, en nie in telegramstyl geskryf moet wees nie.

(7) Definiense moet ter wille van eenvormigheid in 'n kanonieke vorm gereflekteer word, dit wil sê veral in die enkelvoud en in die teenwoordige tyd.

(8) Samestellings moet nie sonder meer uit die som van hul dele gedefinieer word nie.

(9) Waar moontlik, moet in 'n oorkoepelende klas gedefinieer word, dit wil sê by ' $n$ diersoort behoort daar genoem te word of dit gaan om 'n roof-, huis-, soog- of werweldier, ensovoorts.

(10) Definiense moet eerder algemeen as spesifiek wees. 


\section{Verwysings}

\section{A. Woordeboeke}

De Villiers, M. et al. 19856. Nasionale Woordeboek. Kaapstad: Nasou.

Odendal, F.F. et al. 19792. Verklarende Handwoordeboek oan die Afrikaanse Taal. Doornfontein: Perskor.

Schoonees, P.C. / F.J. Snijman / D.C. Hauptfleisch (Reds.). 1950-1984. Woordeboek oan die Afrikamse Taal. Pretoria: Staatsdrukker.

Sinclair, J.M. (Red.). 1988. Collins COBUILD Essential English Dictionary. Londen: Collins.

\section{B. Ander Bronne}

Amold, D.I. 1980-81. College-Level Dictionaries and Freshman Composition. Dictionaries 2-3: 69-79.

Ayto, J.R. 1983. On Specifying Meaning. Hartmann, R.R.K. (Red.). 1983: 89-98.

Bäcklund, U. 1985. "Almost" and "Nearly", Dynamic and Static Meaning. Cahiers de Lexicologie 57(2): 65-120.

Cowie, A.P. 1980-81. Lexicography and its Pedagogic Applications. Applied Linguistics 2(3): 203-206.

Dagenais, L. 1984. Two principles in Definitions of an Explanatory-combinatorial Dictionary. Hartmann, R.R.K. (Red.). 1984: 58-66.

Eksteen, L.C. 1965. Die leksikale definisie. 'n Leksikografiese ondersoek. Ongepubliseerde D.Litt.proefskrif. Universiteit van Pretoria.

Eksteen, L.C. 1967. Die grondslag van gebruik in die verklarende leksikografie. Taalfasette 4: $12-18$

Evans, B. 1969. But What's a Dictionary for? Hogins, J.B. en R.E. Yarber (Reds.). 1969: 212-223.

Gates, E. 1986. Preparation for Lexicography as a Career in the United States. Ilson, R. (Red.). 1986: 82-88.

Geeraerts, D. en J. Janssens. 1982. Wegwijs in woordenboeken. Assen: Van Gorcum.

Gouws, R.H. 1985. Die omvattende sinchroniese woordeboek as taalkundige handleiding. S.A. Tydskrif oir Taalkunde 3(3): 21-47.

Gouws, R.H. 1989. Leksikografie. Pretoria: Academica.

Gove, P.B. 1985. Subject Orientation within the Definition. Zgusta, L. (Red.). 1985: 58-70.

Hanks, P. 1979. To What Extent Does a Dictionary Definition Define? ITL 45-46: 32-38.

Hartmann, R.R.K. (Red.). 1983. Lexicography: Principles and Practice. Londen: Academic Press.

Hartmann, R.R.K. (Red.). 1984. LEXeter' 83 Proceedings. Tübingen: M. Niemeyer.

Heliel, M.H. 1987. Definitions of Linguistic Terms in an English - Arabic Dictionary. Dictionaries 9: $133-148$.

Hogins, J.B. en R.E. Yarber. (Reds.). 1969. Language: An Introductory Reader. New York: Harper and Row.

Hulbert, J.R. 1955. Dictionaries: British and American. Londen: André Deutsch. 
Ilson, R. (Red.). 1986. Lexicography: An Emerging International Profession. Manchester: Manchester University Press.

Katz, J.J. 1972. Semantic Theory. New York: Harper and Row.

Kipfer, B.A. 1984. Workbook on Lexicography. Exeter: A. Wheaton and Co. Ltd.

Landau, S.I. 1984. Dictionaries: The Art and Craft of Lexicography. New York: The Scribner Press.

Leech, G. 1981. Semantics. New York: Penguin Books.

Louw, J.P. (Red.). 1985 Lexicography and Translation. Kaapstad: Bybelgenootskap van S.A.

Magay, T. 1988. On Some Problems of the Bilingual Learner's Dictionary. Snell-Homby, M. (Red.). 1988: 171-177.

McDavid, R.I. Jr. en A.R. Duckert (Reds.). 1973. Lexicography in English. Annals of the New York Academy of Sciences 211. New York: The New York Academy of Sciences.

Neubauer, F. 1984. The Language of Explanation in Monolingual Dictionaries. Hartmann, R.R.K. (Red.). 1984: 117-123.

Odendal, F.F. 1978. Die gesag van die woordeboek. Snyman, H. (Red.). 1978: 65-77.

Odendal, F.F. 1979. Plus positief en plus negatief. Tydskrif vir Geesteswetenskappe 19(1): 24-41.

Otto, A.N. 1989. Kriteria vir 'n Afrikaanse aanleerderwoordeboek. Ongepubliseerde D.Litt.-verhandaling. Universiteit van StelJenbosch.

Petöfi, J.S. 1976. Lexicology, Encyclopedic Knowledge, Theory of Text. Cahiers de Lexicologie 29(2): 25-41.

Quine, W.V. 1973. Vagaries of Definition. McDavid, R.l. Jr. en A.R. Duckert (Reds.). 1973: 247-250.

Quirk, R. 1973. The Social Impact of Dictionaries in the U.K. McDavid, R.I. Jr. en A.R. Duckert (Reds.). 1973: 76-88.

Robinson, R. 1950. Definition. Oxford: Clarendon Press.

Snell-Homby, M. (Red.). 1988. ZüriLEX'86 Proceedings. Tübingen: Francke Verlag.

Snyman, H. (Red.). 1978. Uit vier windstreke. Kaapstad: Nasou.

Van Schalkwyk, D.J. en G. Kroes. 1979. Doeltreffende Afrikans. Goodwood: Nasou.

Wierzbicka, A. 1985. Lexicography and Conceptual Analysis. Ann Arbor: Karoma Publishers, lnc.

Woolf, H.B. 1973. Definition: Practice and Illustration. McDavid, R.J. Jr. en A.R. Duckert (Reds.). 1973: 253-258.

Zgusta, L. 1971. Manual of Lexicography. Den Haag: Mouton.

Zgusta, L. (Red.). 1985. Probleme des Wöterbuchs. Darmstadt. Wissenschaftliche Buchgesellschaft. 